\title{
SOIL ORGANIC CARBON STOCKS UNDER DIFFERENT LAND USES IN CHURE REGION OF MAKAWANPUR DISTRICT, NEPAL
}

\author{
P. Ghimire ${ }^{1^{*}}$, B. Bhatta ${ }^{1}$, B. Pokhrel ${ }^{1}$, G. Kafle ${ }^{1}$ and P. Paudel ${ }^{2}$ \\ ${ }^{1}$ Agriculture and Forestry University, Faculty of Forestry, Hetauda, Nepal \\ 2 Practical Solution Consultancy Nepal, Pvt. Ltd., Kathmandu, Nepal
}

\begin{abstract}
Soil $C$ sequestration through enhanced land use is a good strategy to mitigate the increasing concentration of atmospheric $\mathrm{CO}_{2}$. A study was conducted in Chhatiwan VDC of Makawanpur District to compare soil organic carbon (SOC) stocks of four main land use types such as forest, degraded forest, Khet and Bari land. Stratified random sampling method was used for collecting soil samples. Organic carbon content was determined by Walkley and Black method. Total SOC stock of different types of land followed the order: as Forest $\left(110.0 \mathrm{t} \mathrm{ha}^{-1}\right)>$ Bari $(96.5 \mathrm{t}$ $\left.\mathrm{ha}^{-1}\right)>$ Khet $\left(86.8 \mathrm{t} \mathrm{ha}^{-1}\right)>$ Degraded land $\left(72.0 \mathrm{t} \mathrm{ha}^{-1}\right)$. The SOC\% declined with soil depths. The SOC\% at $0-20 \mathrm{~cm}$ depth was highest $(1.26 \%)$ that recorded in the forest soils and lowest $(0.37 \%)$ at 80 $100 \mathrm{~cm}$ depth in degraded forest land. Thus, the SOC stock varied with land use systems and soil depths. The study suggests a need for appropriate land use strategy and sustainable soil management practices to improve SOC stock.
\end{abstract}

Keywords: Chure, land use, soil organic carbon, soil depth

\section{INTRODUCTION}

Soil is a complex mixture of mineral nutrients, organic matter, water, air, and living organisms determined by various environmental factors such as climate, parent materials, relief, organisms, and time factors (Bajracharaya et al., 2004). Soil contains three times more carbon (C) than in atmosphere and 3.8 times more $\mathrm{C}$ than in biotic pool (Shrestha et al., 2012). Soils are a potentially viable sink for atmospheric carbon (Lal et al., 2012). Soil carbon sequestration is a process of transforming carbon dioxide from the atmosphere into the soil through crop residue and other organic solids, and in a form that is not immediately remitted. (Sundermeier et al., 2005). This transformation has the potential to reduce atmospheric $\mathrm{CO}_{2}$, thereby slowing global warming and mitigating climate change.

\footnotetext{
*Corresponding author email: pghimire@ afu.edu.np
} 
Soil biodiversity has a positive impact on SOC pool. All other factors being equal, ecosystems with high biodiversity sequester more $\mathrm{C}$ in soil and biota than those with reduced biodiversity (Lal et al., 2012). Carbon sequestration from atmosphere can be advantageous from both environmental and socio-economic perspectives. The environmental perspective includes the removal of $\mathrm{CO}_{2}$ from the atmosphere, the improvement of soil quality, and the increase in biodiversity (Batjes, 2014); while socio-economic benefits include increased yields (Sundermeier et al., 2005). Thus, soils play a vital role in maintaining a balanced global carbon cycle. Globally, approximately $1500 \mathrm{Pg}$ of $\mathrm{C}$ is stored in soils in the form of organic matter, approximately twice the atmospheric C pool (Sundermeier et al., 2005). Consequently, the soil organic-carbon pool and its loss through emissions have a significant influence on the $\mathrm{CO}_{2}$ concentration in the atmosphere, and thus on global climate change driven by the greenhouse effect (Genxu et al., 2002).

Land use and soil management practices can significantly influence SOC dynamics and C flux from the soil (Post and Kwon, 2000). SOC content exhibits considerable spatial variability according to land uses and soil depths. Land use and vegetation type influence soil erosion and $\mathrm{C}$ dynamics through its effect on SOC contents, $\mathrm{CO} 2$ flux and dissolved organic carbon (DOC) leaching from soil (Bajracharaya et al., 2004). Land management that exerts the least soil disturbance contributes to increased SOC accumulation, while intensive disturbance results in lower SOC and consequent soil degradation (Post and Kwon, 2000). Soil thus, can be a source or a sink of atmospheric carbon depending upon land use and soil management. Gradual conversion of forest and grassland to cropland has resulted in significant change, depending upon various factors and processes operating in the systems, the most significant being land use, land use change, soil erosion and deforestation (IPCC, 2000). Widespread erosion and landslides along with reduction of the productive forest area and misuse of agrochemicals are the major environmental problems especially in Chure region of Nepal (Regmi, 1999), lowering the carbon sequestration. Spatially distributed estimates of SOC pools and soil C sequestration are important requirements for understanding the role of soils in the global carbon cycle and for assessing potential biosphere responses to climatic change or variation (Lal et al., 2012). In this context, there is dire need to conduct research related to C pools and $\mathrm{C}$ sequestration among different land uses. Few studies have been conducted in Nepal, in related to carbon sequestration in the context of climate change and the studies are focused on biomass carbon and haves largely ignored soil organic carbon. Therefore, the present study aims to provide the base line information for carbon sequestration potential of soil of different land uses in Chure region of central Nepal. 


\section{MATERIALS AND METHODS}

\section{Study Area}

The study site, Chhatiwan Village Development Committee (VDC) of Makawanpur district, experiences tropical climate with characteristic monsoon rainfall and three distinct seasons: hot and dry summer (March to Mid-June), hot and moist rainy season (Mid June to September) and cold and dry winter (October to February). Average rainfall is $2274 \mathrm{~mm}$ in Churia hills. The majority soil in this area is sandy loam. The study area is environmentally vulnerable due to occurrence of landslide, soil erosion, and deforestation.

Broadly, the study site can be divided in-to forest, cultivable land (Khet and Bari) and degraded land. The area is mainly tropical forest mixed with Shorea robusta forest with other species such as Terminalia alata, Terminalia belerica etc. Two major types of agricultural lands are Khet (irrigated low land) and Bari (rain-fed upland). Maize and potato are the principal crops in Bari and paddy is the principal crop in Khet. Farmyard manure and compost (made from forest products used for animal bedding) are the major nutrient sources for crops in addition to some chemical fertilizers. Degraded land characterized by barren areas, with presence of trees, shrubs, or grasses is vulnerable to soil erosion. The criteria for classification of land uses are - Forest: all land with forest cover i.e. with trees whose crown covers are at least 10\% not being used primarily for purpose other than forestry (DFRS, 1999) and degraded land: land with stocking class i.e. crown cover is less than $10 \%$, or area with prominent soil erosion, deforestation and degradation etc. (DFRS, 1999). They may contain barren areas, trees, shrubs, or grasses. Khet refers to land use which is relatively alluvial flat land/ lowland/terraces having irrigation facility during drying season, primarily cultivated for rice, paddy etc. (Paudel and Thapa, 2001) and Bari refers land with higher elevation than Khet land i.e. rain fed terraces suitable primarily for maize, potato, millet etc. (Paudel and Thapa, 2001).

\section{Soil Sampling}

The stratified random sampling method was adopted for the study. The starting point was selected randomly. Samples were taken from each land uses with $\mathrm{W}$-type shape sample. Soil samples were collected from five replicated sites of each land uses types within the study area. In each sampling site, a pit of $30 \mathrm{~cm}$ by $100 \mathrm{~cm}$ pit was dug and undisturbed soil core samples were taken by a cylindrical core sampler $(5.5 \mathrm{~cm}$ diameter and $10 \mathrm{~cm}$ height) from the $0-20 \mathrm{~cm}, 20-40 \mathrm{~cm}, 40-60 \mathrm{~cm}, 60-80 \mathrm{~cm}$ and $80-$ $100 \mathrm{~cm}$ soil depths for the determination of bulk density. The bulk soil samples were oven dried, sieved through a $2 \mathrm{~mm}$ sieve and carefully stored before basic considerations.

\section{Soil Analysis}

Soil bulk density was determined using core sampling method (Blake and Hartge, 1986). Oven dry (at $105{ }^{\circ} \mathrm{C}$ ) soil samples were used for moisture correction. Bulk density was calculated by the following formula; 
Bulk density $\left(\mathrm{gm} \mathrm{cm}^{-3}\right)=($ Oven dry weight of soil in $\mathrm{gm}) /($ Volume of the soil in $\mathrm{cm}^{3}$ )

Where,

Volume of the soil= Volume of core - Volume of the stone

Soil Organic carbon (SOC) percent was analyzed using the Walkley-Black wet oxidation method as described by Walkley and Black (1934). This method is based on the oxidation of organic matter by potassium dichromate $\left(\mathrm{K}_{2} \mathrm{Cr}_{2} \mathrm{O}_{7}\right)$ and sulfuric acid mixture, followed by titration of the excessive dichromate by a ferrous ammonium sulfate $\left(\mathrm{Fe}\left(\mathrm{NH}_{4}\right) 2\left(\mathrm{SO}_{4}\right) 2 * 6 \mathrm{H}_{2} \mathrm{O}\right)$. Total SOC was estimated using following formula by (Chhabra et al., 2003).

$\mathrm{SOC}=$ Organic carbon content $\% \mathrm{x}$ soil bulk density $\left(\mathrm{gm} \mathrm{cm}^{-3}\right) \mathrm{x}$ thickness of horizon $(\mathrm{cm})$

\section{RESULTS}

\section{Bulk Density}

The BD increased with soil depths for all land uses. The minimum BD, $1.04 \mathrm{gm} \mathrm{cm}^{-3}$, was found at the top soil i.e. $0-20 \mathrm{~cm}$ depth in the forest land and the maximum BD, $1.45 \mathrm{gm} \mathrm{cm}^{-3}$, was found at 80-100 $\mathrm{cm}$ depth in Khet land (Table 1).

Table 1. Bulk density $\left(\mathrm{gm} \mathrm{cm}^{-3}\right)$ of soil at different depths in different land uses

\begin{tabular}{l|c|c|c|c|c|c|c|c}
\hline \multirow{2}{*}{$\begin{array}{c}\text { Soil Depth } \\
(\mathrm{cm})\end{array}$} & \multicolumn{10}{c|}{ Land uses } \\
\cline { 2 - 10 } & \multicolumn{2}{|c|}{ Forest } & \multicolumn{2}{c|}{ Degraded land } & \multicolumn{2}{c|}{ Khet } & \multicolumn{2}{c}{ Bari } \\
\cline { 2 - 10 } & Mean & SD & Mean & SD & Mean & SD & Mean & SD \\
\hline $0-20$ & 1.04 & 0.12 & 1.31 & 0.04 & 1.24 & 0.4 & 1.15 & 0.05 \\
$20-40$ & 1.13 & 0.08 & 1.36 & 0.05 & 1.35 & 0.06 & 1.29 & 0.06 \\
$40-60$ & 1.19 & 0.04 & 1.39 & 0.06 & 1.37 & 0.10 & 1.33 & 0.05 \\
$60-80$ & 1.21 & 0.07 & 1.40 & 0.06 & 1.39 & 0.10 & 1.41 & 0.07 \\
$80-100$ & 1.32 & 0.11 & 1.43 & 0.08 & 1.45 & 0.08 & 1.44 & 0.09 \\
Average & 1.18 & & 1.38 & & 1.36 & & 1.32 & \\
\hline
\end{tabular}

Higher BD was found in cultivable land which was probably due to continuous cultivation and a lower turnover of organic matter in soil as cultivation often leads to soil compaction which increases $\mathrm{BD}$ and decreases pore volume. On the contrary, Bhandari and Bam (2013) reported higher BD in forest land. 
Bulk density of a soil is a dynamic property depending on the soil structural conditions. The increasing soil BD with increasing soil depths could be due to lower organic matter contents, less aggregation, fewer roots and other soil dwelling organisms and soil compaction ( Liefeld et al., 2005). Chaudhari et al (2013) reported that with increasing soil depth the organic matter content of soil decreases and which leads to decrease in porosity of soil and also to the compaction of soil.

\section{Soil Organic Carbon}

SOC was found ranging from $0.45 \%$ to $1.26 \%$ in the study area (Table 2).

Table 2. SOC percentage of different land uses at different soil depths

\begin{tabular}{l|c|c|c|l|l|l|l|l}
\hline \multirow{2}{*}{$\begin{array}{l}\text { Soil Depth } \\
(\mathrm{cm})\end{array}$} & \multicolumn{8}{|c|}{ Average SOC percentage (\%) } \\
\cline { 2 - 10 } & \multicolumn{2}{|c}{ Forest } & \multicolumn{2}{c}{ Degraded land } & \multicolumn{2}{c|}{ Khet } & \multicolumn{2}{c}{ Bari } \\
\cline { 2 - 10 } & Mean & \multicolumn{1}{|c|}{ SD } & Mean & SD & Mean & SD & Mean & SD \\
\hline $0-20$ & 1.26 & 0.0 & 0.71 & 0.05 & 0.91 & 0.10 & 1.01 & 0.10 \\
$20-40$ & 1.02 & 0.10 & 0.58 & 0.05 & 0.73 & 0.09 & 0.86 & 0.11 \\
$40-60$ & 0.93 & 0.10 & 0.52 & 0.02 & 0.61 & 0.06 & 0.71 & 0.08 \\
$60-80$ & 0.81 & 0.09 & 0.45 & 0.05 & 0.53 & 0.07 & 0.62 & 0.03 \\
$80-100$ & 0.72 & 0.07 & 0.37 & 0.03 & 0.45 & 0.06 & 0.51 & 0.05 \\
\hline
\end{tabular}

The SOC content percent was found higher in the upper layers which could be related to higher soil organic matter content, and less influence of parent materials. As reported by Lal (2005), most of the soils contained between 0.3 and $11.5 \%$ Soil Organic Matter (SOM) in the surface $20 \mathrm{~cm}$ of mineral soil. The forest soil had the highest SOC percentage $(0.95 \%)$, followed by Bari $(0.74 \%)$, Khet $(0.65 \%)$ and degraded land $(0.52 \%)$. This result agrees well with that of Islam and Weil (2000), who reported that the SOC content percent in the soil of cultivated land was lower than that of forest and grassland. The lower SOC content in Khet and Bari soil probably reflects continuous cultivation with minimum addition of SOM and sandy textured soil (Poudel and Thapa, 2001). 
Table 3. Total SOC of different land uses at different soil depths

\begin{tabular}{l|c|c|c|c|c|c|c|c}
\hline \multirow{2}{*}{$\begin{array}{l}\text { Soil Depth } \\
(\mathrm{cm})\end{array}$} & \multicolumn{10}{c}{ SOC $\left(\mathrm{t} \mathrm{ha}^{-1}\right)$} \\
\cline { 2 - 10 } & \multicolumn{2}{|c}{ Forest } & \multicolumn{2}{c|}{ Degraded land } & \multicolumn{2}{c|}{ Khet } & \multicolumn{2}{c}{ Bari } \\
\cline { 2 - 10 } & Mean & SD & Mean & SD & Mean & SD & Mean & SD \\
\hline $0-20$ & 26.2 & 3.96 & 18.60 & 1.69 & 22.6 & 2.20 & 23.2 & 3.36 \\
$20-40$ & 23.1 & 1.75 & 15.77 & 1.71 & 19.7 & 2.61 & 22.2 & 3.93 \\
$40-60$ & 22.1 & 2.97 & 14.45 & 0.57 & 16.7 & 1.23 & 18.9 & 2.92 \\
$60-80$ & 19.6 & 1.09 & 12.60 & 1.09 & 14.7 & 3.02 & 17.5 & 1.77 \\
$80-100$ & 19.0 & 3.88 & 10.58 & 0.74 & 13.1 & 2.69 & 14.7 & 2.43 \\
Total & 110.0 & 72.0 & 86.8 & 96.5 & \\
\hline
\end{tabular}

Comparison of SOC in natural and cultivated land gives some insight into the management effect on SOC content. It indicates that land use practices have made significant impact on total SOC stock. A decreasing trend in soil organic carbon was seen for all the land uses with increase in soil depths, which ranged from $26.2 \mathrm{t} \mathrm{ha}^{-1}$ to $19.0 \mathrm{t} \mathrm{ha}^{-1}$ for Forest soil for the depths $0-20 \mathrm{~cm}$ to $80-100 \mathrm{~cm}$ respectively. The trend was the same for cultivated land (both Bari and Khet) and degraded forest land, where SOC values decreased with increasing depths, ranging from $23.2 \mathrm{t} \mathrm{ha}^{-1}$ to $14.7 \mathrm{t}$ $\mathrm{ha}^{-1}, 22.6 \mathrm{t} \mathrm{ha}^{-1}$ to $13.1 \mathrm{t} \mathrm{ha}^{-1}$ and 18.6 to $10.6 \mathrm{t} \mathrm{ha}^{-1}$ respectively for Bari, Khet and degraded forest land.

The total SOC stock followed the order as Forest $>$ Bari $>$ Khet $>$ Degraded land with the total SOC stock in each land use being $110.0 \mathrm{t} \mathrm{ha}^{-1}, 96.5 \mathrm{tha}^{-1}, 86.8 \mathrm{tha}^{-1}$ and 72.0 $\mathrm{t}$ ha ${ }^{-1}$ respectively.

\section{Relation between BD, SOC percentage and Total SOC}

Relationship between BD and carbon content of soil is non-linear or polynomial based on the type of soil and amount of parent materials available in soil (Chaudhari et al., 2013). The study concluded that three is a linear relationship (adjusted $\mathrm{R}^{2}$ value $0.74,0.94,0.92$ and 0.87 for forest, degraded forest, Khet and Bari, respectively) between SOC stock and organic carbon percentage for all types of land use (Figures $3,4,5$ and 6 ).

However, there was no linear relationship (adjusted $\mathrm{R}^{2}$ value $0.30,0.19,0.08$ and 0.07 for forest, degraded forest, Khet and Bari, respectively) between bulk density and total SOC content. This implies that the quantity of organic carbon stored in the soil is governed by SOC percentage and BD. Thus, improvement of SOC percentage and soil quality maintenance is an important intervention to increase SOC storage capacity. 


\section{DISCUSSION}

The soil organic carbon in forest soil depends upon forest types, climate, moisture, temperature and types of soil (Chaudhari et al., 2013). The variables investigated for the study were soil BD, SOC content percent and SOC stock. Significant variations in all tested variables were found among all the land uses. There was a distinct variation in the BD with respect to soil depths among all the land uses. Indeed there was a gradual increase of BD with the increase in soil depth for all four land uses. The top soil layer had lower BD indicating that the soil was better for plant growth compared to other soil depths which could be attributed to the higher SOC content percent in the top layer of soil. The BD depends on various factors such as compaction, consolidation and amount of SOC present in the soil but is negatively correlated to the organic carbon content (Morisada et al., 2004). Ali et al (2017) also reported SOC stock had negative correlation with BD as lower soil layer contains lower SOC content. Lower organic contents, less aggregation, fewer roots and other soil dwelling organisms and compaction caused by the weight of the overlying layers increases the bulk density of soil (Brady 1999).

The study shows that soil under forest land had higher SOC than cultivated land and degraded land. As we could see cultivated land was highly disturbed with tillage farming and heavy uses of chemical fertilizers whereas the forest land was less disturbed with adequate vegetation cover. Conventional agricultural system can decrease soil organic carbon (Liefeld et al., 2005). Higher SOC stock in the forest soil can be attributed to higher organic input from litter fall and lower soil disturbance compared to cultivated land (Dhakal et al., 2010). Shrestha and Singh (2008) reported that leaf litter, and root litter inputs play a major role in forest soil carbon dynamics. Comparatively lower SOC stock in degraded forest land might be due to lower amount of organic matter which could be attributed to lower inputs of leaf litter, low decomposition of fine roots, greater soil disturbance, lower root biomass and loss of vegetation cover (Lal et al., 2012). Depth wise average SOC results are mentioned in Figure 2. A significantly higher SOC stock was observed in the top soil than in other depths within the profile of the same land use. As we can see SOC decreases with the increase in soil profile depth. It may be due to less leaching of dissolved organic content (DOC) and hence less accumulation at lower depths. The ease and speed with which SOC becomes available is related to the soil organic matter fraction in which it resides. SOM contains approximately $58 \%$ of organic carbon (Sakin et al., 2011). Leaf litter inputs, root biomass, vegetative residues and available nutrients of the soil played an important role and influenced the amount of organic matter in soils (Shrestha and Singh, 2008). Ali et al (2017) also reported that higher SOC stock in forest land compared to arable land and pasture land. Comparatively higher SOC stock in top layer could be due to high organic matter content, low soil disturbance, greater root biomass and returns of vegetative residue. The results seem to be justified as Bajracharya (2004) who concluded that land use had a significant effect on the SOC content in the soil profile and soils under natural vegetation had a higher SOC content in soil compared to cultivated soil. 

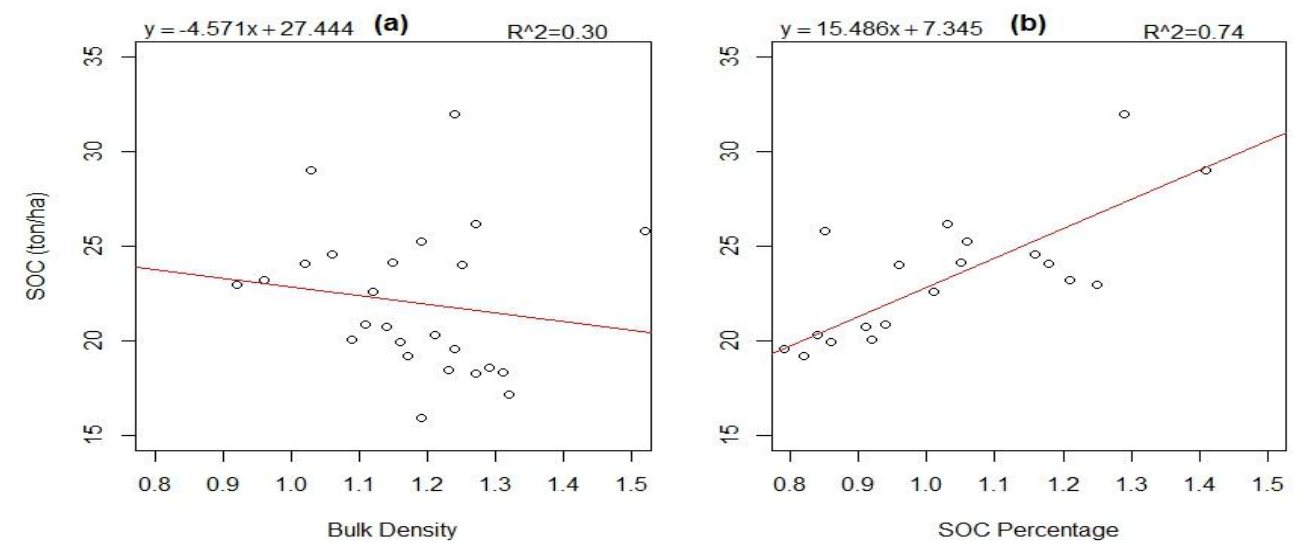

Figure 3. (a) SOC content $\left(\mathrm{t} \mathrm{ha}^{-1}\right)$ and BD $\left(\mathrm{g} \mathrm{cm}^{-3}\right)$, (b) SOC Content $\left(\mathrm{t} \mathrm{ha}^{-1}\right)$ with organic carbon content percentage of forest
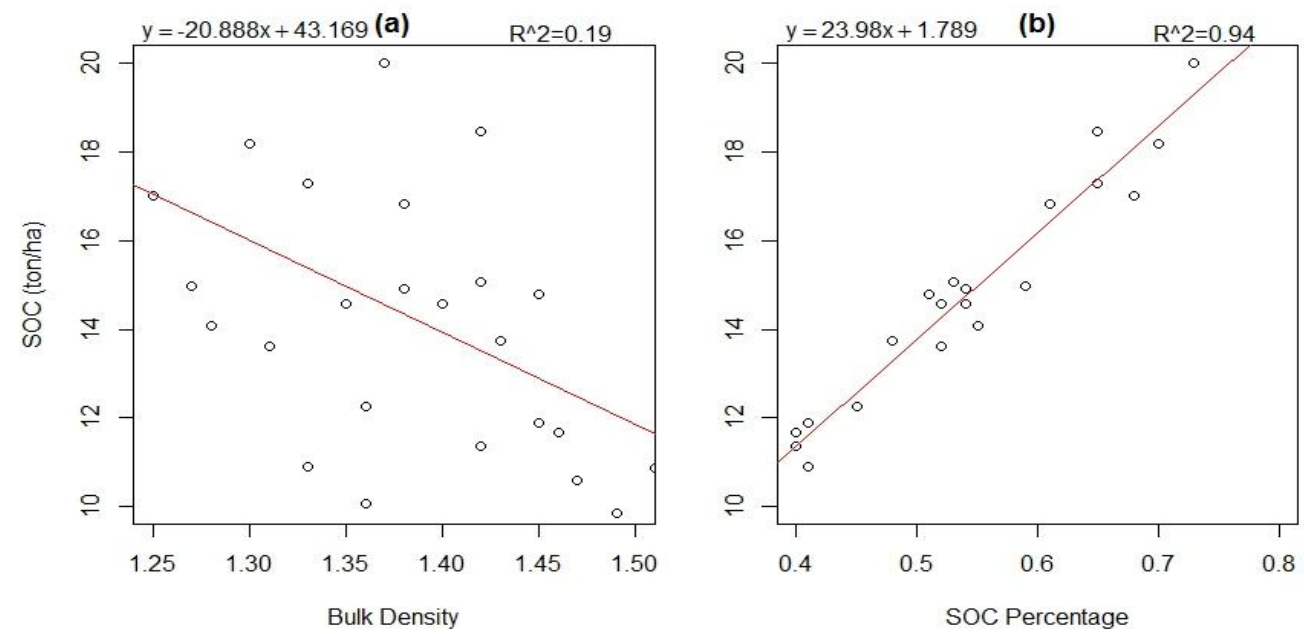

Figure 4. (a) SOC content $\left(\mathrm{t} \mathrm{ha}^{-1}\right)$ and BD $\left(\mathrm{g} \mathrm{cm}^{-3}\right)$, (b) SOC Content $\left(\mathrm{t} \mathrm{ha}^{-1}\right)$ with organic carbon content percentage of Degraded land 

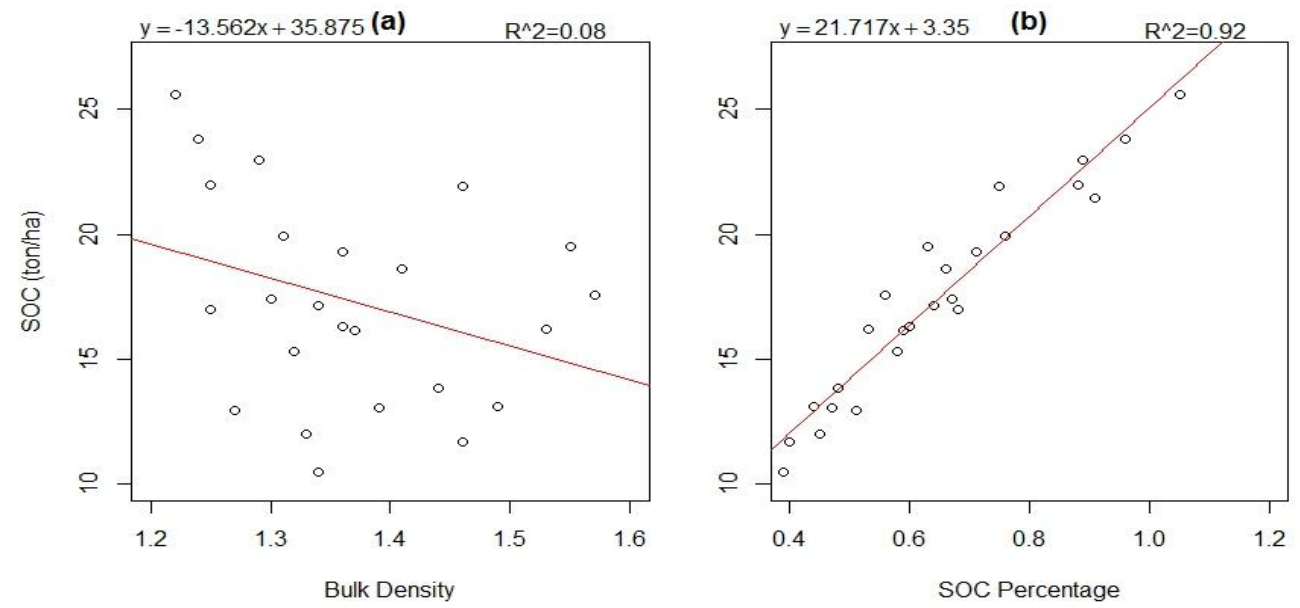

Figure 5. (a) SOC content $\left(\mathrm{t} \mathrm{ha}^{-1}\right)$ and BD $\left(\mathrm{g} \mathrm{cm}^{-3}\right)$, (b) SOC Content $\left(\mathrm{t} \mathrm{ha}^{-1}\right)$ with organic carbon content percentage of Khet
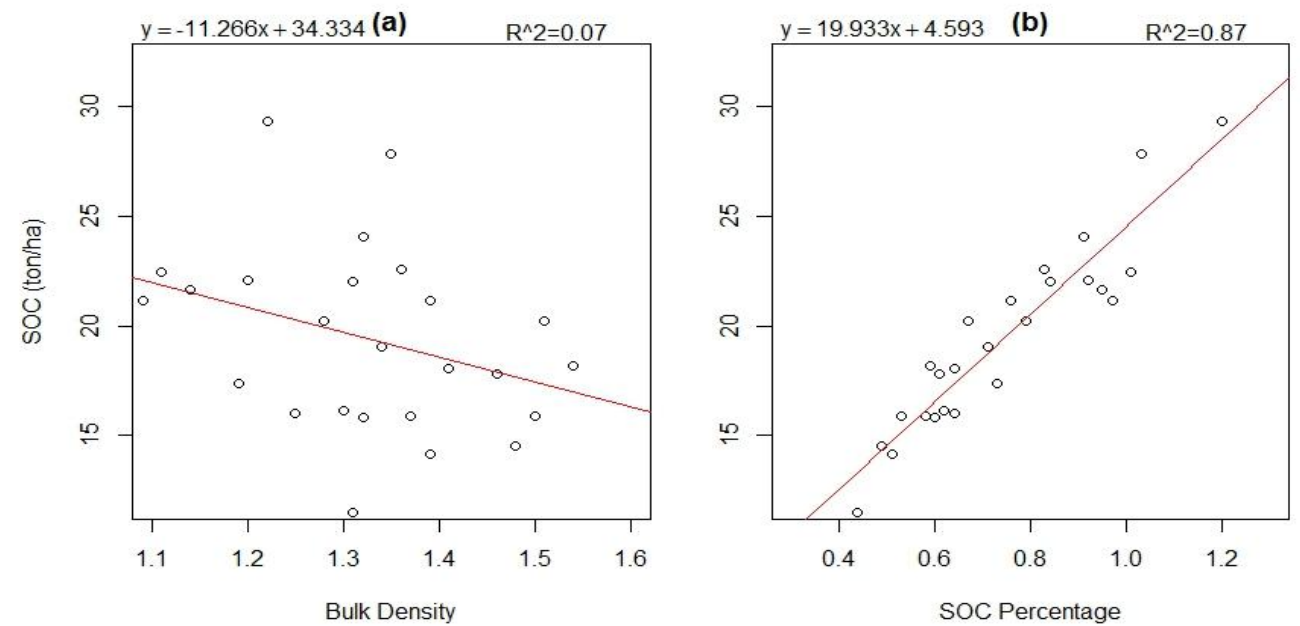

Figure 6. (a) SOC content $\left(\mathrm{t} \mathrm{ha}^{-1}\right)$ and BD $\left(\mathrm{g} \mathrm{cm}^{-3}\right)$, (b) SOC Content $\left(\mathrm{t} \mathrm{ha}^{-1}\right)$ with organic carbon content percentage of Bari 
P. Ghimire et al.

\section{CONCLUSION}

Land use and soil depth both affected SOC stock significantly. The total SOC followed the order as Forest $>$ Bari $>$ Khet $>$ Degraded forest land with the total SOC stocks of each land uses as $110.0 \mathrm{t} \mathrm{ha}^{-1}, 96.5 \mathrm{t} \mathrm{ha}^{-1}, 86.8 \mathrm{t} \mathrm{ha}^{-1}$ and $72.0 \mathrm{t} \mathrm{ha}^{-1}$ respectively. Bulk density (BD) was found to be increasing with increases in the depth of soil profile for all the land uses which shows negative co-relation with SOC whereas soil organic carbon percentage was decreasing with increase in depth of the soil profile. This implies that the quantity of organic carbon stored in the soil and land use is governed by SOC percentage and BD. Hence, appropriate land use strategy and sustainable soil management practices are most important interventions to increase SOC storage capacity of different land use systems.

\section{ACKNOWLEDGEMENTS}

We gratefully acknowledge the Directorate of Research and Extension, Agriculture and Forestry University, Nepal for providing fund for this research work. We are thankful to the Regional Soil Laboratory, Hetauda for extending laboratory facilities.

\section{REFERENCES}

Ali, S., Begum, F., Hayat, R., and Bohannam, B.J.M. (2017). Variation in soil organic carbon stock in different land uses and altitudes in Bagrot Valley, Northern Karakoram. Acta Agriculturae Scandinavica, Section B- Soil and Plant Science. Vol.67, (2017) 551-561.

Bajracharya, R.M., Sitaula, B.K., Shrestha, B.M., Awasthi, K.D., Balla, M.K., and Singh, B.R. (2004). Soil organic carbon status and dynamics in the central Nepal Middle Mountains. Journal of Institute of Forestry. 12, 28-44.

Batjes, N.H. (2014). Landmark Papers Total carbon and nitrogen in the soils of the world. European Journal of Soil Science, Vol(65). Landmark Papers: No. 3.

Bhandari, S., and Bam, S. (2013). Comparative Study of Soil Organic Carbon (SOC) under Forest, Cultivated and Barren land: A Case of Chovar Village, Kathmandu. Nepal Journal of Science and Technology Vol.14, No.2 (2013) 103-108.

Brady, N.C., and Weil, R.R. (2017). The nature and properties of soil. 15th ed. Macmillan Publishing Company, U.S.A.

Chaudhari, P.R., Ahire, D.V., Ahire, V.D., Chkravarty, M., and Maity, S. (2013). Soil Bulk Density as related to Soil Texture, Organic Matter Content and available total Nutrients of 3,1-8.

Chhabra, A., Palria, S., and Dadhwal, V.K. (2003). Soil organic carbon pool in Indian forests. Forest Ecology and Management 173, 187-199. doi:10.1016/S0378-1127(02)00016-6.

DFRS. (1999). Forest Resources Nepal (1987-98). Forest Resource Information System Project, HMGN/FINNIDA/DFRS, Kathmandu, Nepal.

Dhakal, S., Koirala, M., Sharma, E., and Subedi, N.R. (2010). Effect of Land Use Change on Soil Organic Carbon Stock in Balkhu Khola Watershed Southwestern Part of Kathmandu Valley, Central Nepal. Conference Paper: World Academy of Science, Engineering and Technology, June 2010. 
Genxu, W., Ju, Q., Guodong, C., and Yuanmin, L. (2002). Soil organic carbon pool of grassland soils on the Qinghai-Tibetan Plateau and its global implication. The Science of the Total Environment 291, 207-217.

IPCC. (2000). The Intergovernmental Panel on Climate Change, Special Report on Land Use, Land-Use Change and Forestry. Cambridge University Press, Cambridge, UK.

Islam, K.R., and Weil, R.R. (2000). Land use effect on soil quality in a tropical forest ecosystem of Bangladesh. Agric. Ecosyst. Environ. 79: 9-16.

Lal, S.H., Bajracharya, R.M., and Sitaula, B.K. (2012). Forest and Soil Carbon Stocks, Pools and Dynamics and Potential Climate Change Mitigation in Nepal, 1, 800-811.

Liefeld, J., Bassin, S., and Fuhrer, J. (2005). Carbon stock in Swiss agriculture soils predicted by land use soil characteristics and altitude. Agriculture, Ecosystem and Environment 105: 225-266.

Morisada, K., Ono. K., and Kanomata, H. (2004). Organic carbon stock in forest soils in Japan. Geoderma 119:21-32.

Post, W.M., and Kwon, W.M. (2000). Soil carbon sequestration and land-use change: processes and potential. Global Change Biol. 6, pp 317-327.

Poudel, G.S., and Thapa, G.B. (2001). Changing farmer's land management practices in the hills of Nepal. Environ. Manage. 28:789-803.

Regmi, P.P. (1999). Agricultural development through eco-restructuring in different ecological zones across Nepal. PhD Dissertation AIT AC99-2.Asian Institution of Technology, Bangkok, Thailand. Pp. 102-145.

Sakin, E., Deliboran, A., and Tutar, E. (2011). Bulk density of the Harran Plain soils in relation to other soil properties. Afr. J. agric. Res. 6(7):1750- 1757.

Shrestha, B.M. and Singh, B.R. (2008). Soil and vegetation carbon pools in a mountain watershed of Nepal. Nutrient cycling in agro-ecosystems 81: 179-191.

Shrestha, H.L., Bajracharya, R.M. and Sitaula, B.K. (2012). Forest and Soil Carbon Stocks, Pools and Dynamics and Potential Climate Change Mitigation in Nepal 1, 800-811.

Sundermeier, A., Reeder, R., and Lal, R. (2005). Soil carbon sequestration fundamentals. Rep. No. OSU Factsheet AEX-510-05. OSUE, Columbus, OH.

Walkley, A., and Black, I.A. (1934). An examination of Degtjareff method for determining soil organic matter and a proposed modification of the chromic acid titration method. Soil Sci. 37: 29-37. 